\title{
Effect of partial replacement of soybean and corn with raw or processed chickpea
}

\author{
A.Y. Şengü̈l" \& S. Çalişlar ${ }^{2}$ \\ ${ }^{1}$ Bingol University Faculty of Agriculture, Department of Animal Science, Bingol, Turkey \\ ${ }^{2}$ Kahramanmaras Sutcu Imam University Faculty of Agriculture, Department of Animal Science, Kahramanmaras, Turkey
}

(Submitted 25 December 2019; Accepted 26 February 2020; First published online 13 July 2020)

\author{
Copyright resides with the authors in terms of the Creative Commons Attribution 4.0 South African Licence. \\ See: http://creativecommons.org/licenses/by/4.0/za \\ Conditions of use: The user may copy, distribute, transmit and adapt the work, but must recognise the authors and the \\ South African Journal of Animal Science.
}

\begin{abstract}
This study was conducted to investigate the effects of using raw and processed chickpeas in various ways and levels in rations of egg-laying quail on egg yolk fat content, egg yolk fatty acid profile and some blood parameters. Chickpeas were used raw, autoclaved, and microwaved, and were included in the rations on two levels $(20 \%$ and $40 \%)$. The treatments were designed as seven groups, consisting of control, $20 \%$ and $40 \%$ raw, $20 \%$ and $40 \%$ autoclaved, and $20 \%$ and $40 \%$ microwaved. Each group was designed as three repetitions. Quail were housed in multi-storey cages for nine weeks. As a result, the differences between the control and treatment groups were significant $(P<0.05, P<0.01)$ in terms of the ratios of linoleic acid, $\alpha$ linoleic acid, total saturated fatty acids, and palmitic acid among the egg yolk fatty acids and significant in the ALT levels of the blood parameters $(P<0.01)$, and not significant for the other parameters.
\end{abstract}

Keywords: blood parameters, chickpeas, cholesterol, fatty acids, quail

\#Corresponding author: yusufsengul24@hotmail.com

\section{Introduction}

Soybean meal, an important source of protein, is used in the feeding of poultry in particular. However, because genetically modified soybean has increased rapidly in recent years, it raises concerns about the use of this product. When it is used in animal feeds, there is still insufficient information as to whether the products obtained from those animals constitute a threat to human health.

Among the primary sources of protein that may be regarded as alternatives to soybean meal are derivatives of other legume grains. Grain legumes contain high nutritional values, but also antinutritional factors. These anti-nutritional factors may lead to negative effects on animal metabolism and performance (Gatel, 1994; Kaya \& Yalcin, 1999) On the other hand, the effects of these factors can vary according to type of livestock (Kumar, 1992). The use of legume grains in feeding monogastric animals is limited due to the presence of anti-nutritional factors, such as protease inhibitors, saponins, pyrimidine glycosides, lectins, tannins, and alkaloids (Kaya \& Yalcin, 1999; Jezierny et al., 2010).

Various practices are carried out to remove or reduce the harmful effects of anti-nutritional factors when using legume grains in animal feeds. The goal of thermal processing of grain legumes for poultry nutrition is to increase the nutritional value of the feed and maximize bird performance (Nahavandinejad et al., 2014). These include removing the grain chaff, breaking the integrity of the grain (grinding, crushing), heating (dry heat roasting, cooking in water, steaming), treating with water and various chemical substances, and fermenting (Kaya \& Yalcin, 1999). Processes such as boiling, cooking under pressure, frying, roasting, germinating and fermenting increase the in-vitro digestibility of legume starches. This increase results from the starch granules swelling, rupturing, and separating into a variety of components during cooking. It also ensures a-amylase inhibitors are inactivated.

Microwave irradiation has begun to be used to remove antinutritional factors. Microwaves are used in the food industry for purposes including heating, drying, lyophilizing, cooking, sterilizing, and evaporating liquid disinfectants (Ozdemir et al., 2003). Heating with microwave energy provides advantages over other heat sources in some applications. For example, energy is transformed into direct heat in the material, it allows instant control, and it does not create an electrical stress on the material that would distort its structure. Thus, process control can be more precise than in other methods (Gungor \& Atalay, 1999; Eskibalci \& Ozkan, 2008). 
Among the important legumes that can be used in animal feeding are chickpeas. Chickpeas are commonly used as a protein source in the meals of human beings and in the rations of animals. Chickpeas are thought to be an alternative to soybean meal in animal feeding. The average protein content of chickpeas as feed material is around $21.7 \%$ (Ayasan et al., 2018). Raw chickpea seeds may be used as the primary protein source in poultry diets (Muszyński et al., 2018). They may be added at a rate of $200 \mathrm{~g} / \mathrm{kg}$ to support growth and not cause loss of egg yield, but must be subjected to heat treatments to be used at higher rates (Bampidis \& Christodoulou, 2011). Therefore, the objective of this study was to determine the effects of using grain chickpeas that were raw, autoclaved or processed in a microwave as a protein source in rations for Japanese quail (Coturnix coturnix japonica) on egg yolk fat content, egg yolk fatty acid profile and serum constituents during the laying period.

\section{Materials and Methods}

All procedures were consistent with the ethical standard indicated in directive 2010/63/EU. The experimental protocols were approved by the Animal Experimentation Ethics Committee of Kahramanmaras Sutcu Imam University (Protocol no KSUZIRHAYDEK2014/02-9).

Nutrient analyses of feedstuffs in the experimental rations were conducted in advance, and the rations were prepared based on the results of these analyses. The experiment consisted of seven groups fed with seven rations (Table 1), namely control (C0), which contained no chickpeas, $20 \%$ raw chickpeas (RC20), $40 \%$ raw chickpeas (RC40), 20\% autoclaved chickpeas (OC20), 40\% autoclaved chickpeas (OC40), $20 \%$ microwave-processed chickpeas (MC20), and 40\% microwave-processed chickpeas (MC40).

Table 1 Ingredients of experimental diets for laying Japanese quail in which chickpeas replaced corn and soybean diets $(\mathrm{g} / \mathrm{kg})$

\begin{tabular}{lrrrrrrr}
\hline Ingredients & \multicolumn{1}{c}{ C0 } & RC20 & RC40 & OC20 & OC40 & MC20 & MC40 \\
\hline Corn & 535.02 & 401.96 & 268.90 & 401.96 & 268.90 & 401.96 & 268.90 \\
Soybean meal & 319.70 & 257.44 & 195.13 & 257.44 & 195.13 & 257.44 & 195.13 \\
Chickpeas & 0 & 200.00 & 400.00 & 200.00 & 400.00 & 200.00 & 400.00 \\
Soybean oil & 53.30 & 49.30 & 45.30 & 49.30 & 45.30 & 49.30 & 45.30 \\
Marble powder & 66.81 & 66.60 & 66.40 & 66.60 & 66.40 & 66.60 & 66.40 \\
DCP & 17.63 & 17.72 & 17.83 & 17.72 & 17.83 & 17.72 & 17.83 \\
Methionine & 0.98 & 1.33 & 1.67 & 1.33 & 1.67 & 1.33 & 1.67 \\
Lysine & 2.06 & 1.15 & 0.27 & 1.15 & 0.27 & 1.15 & 0.27 \\
Salt & 2.00 & 2.00 & 2.00 & 2.00 & 2.00 & 2.00 & 2.00 \\
Vit-min premix & 2.50 & 2.50 & 2.50 & 2.50 & 2.50 & 2.50 & 2.50 \\
\hline
\end{tabular}

${ }^{1}$ Vitamin A: $12000000 \mathrm{IU}$, vitamin $\mathrm{D}_{3}: 2000000 \mathrm{IU}$, vitamin E: $35000 \mathrm{mg}$, vitamin $\mathrm{K}_{3}: 5000 \mathrm{IU}$, vitamin $\mathrm{B}_{1}: 3000 \mathrm{mg}$, vitamin $B_{2}: 6000 \mathrm{mg}$, vitamin $B_{6}: 5000 \mathrm{mg}$, vitamin $B_{12}: 15 \mathrm{mg}$, vitamin C: $50000 \mathrm{mg}$, D-Biotin: $45 \mathrm{mg}$, niacin: $20000 \mathrm{mg}$, Ca D-pantothenate: $6000 \mathrm{mg}$, folic acid: $750 \mathrm{mg}$, choline chloride: $125000 \mathrm{mg}$, manganese: $80000 \mathrm{mg}$, iron: $60000 \mathrm{mg}$, zinc: $60000 \mathrm{mg}$, copper: $5000 \mathrm{mg}$, iodine: $1000 \mathrm{mg}$, cobalt: $200 \mathrm{mg}$, selenium: $150 \mathrm{mg}$, canthaxanthin: $15.000 \mathrm{mg}$, ßapo-8'-carotenoic acid ethyl ester: $5.000 \mathrm{mg}$; DCP: dicalcium phosphate

C0: control, RC20: 20\% raw chickpeas, RC40: 40\% raw chickpeas, OC20: 20\% autoclaved chickpeas (OC20), OC40: 40\% autoclaved chickpeas, MC20: 20\% microwaved chickpeas, MC40: 40\% microwaved chickpeas

The industrial residual chickpea feed for the experiment was obtained from a private company and ground to a size that could pass through a 2-mm diameter sieve in the feed crusher. For C0, RC20 and RC40 the ground chickpeas were fed raw, whereas the others were processed with heat treatments. For OC 20 and OC40 the ground chickpeas were put in sacks and autoclaved at $110^{\circ} \mathrm{C}$ for 15 minutes and allowed to reach room temperature before being taken to the feed mixer. For MS20 and MC40 the whole chickpeas were soaked in water at the rate of 1 unit of chickpeas to 4 units of water for 12 hours. The chickpeas were then drained, placed in glass containers and heated in a microwave oven at 900 watts for 8 minutes. After the microwave treatment was completed, the chickpeas were dried $50^{\circ} \mathrm{C}$ for 20 hours. The dried chickpeas were taken to the feed crusher and ground to a size that could pass through a $2-\mathrm{mm}$ diameter sieve. These 
processes caused changes in the condensed tannin content and nutritional composition of the chickpeas (Table 2). The fatty acid content of the raw chickpeas is given in Table 3.

Table 2 Analysed nutrient composition and condensed tannin content of chickpeas treated in autoclave and microwave

\begin{tabular}{|c|c|c|c|c|}
\hline & & Raw chickpeas & Autoclaved chickpeas & Microwaved chickpeas \\
\hline \multicolumn{2}{|l|}{ Dry matter, \% } & 93.48 & 91.36 & 94.33 \\
\hline \multirow[t]{4}{*}{ Condensed tannin $\mathrm{g} / \mathrm{kg}$} & Test 1 & 3.07 & 1.54 & 2.91 \\
\hline & Test 2 & 3.17 & 1.41 & 2.35 \\
\hline & Test 3 & 3.05 & 1.49 & 2.99 \\
\hline & Average & 3.10 & 1.48 & 2.75 \\
\hline \multicolumn{2}{|l|}{ Crude protein, \% } & 20.65 & 19.04 & 20.01 \\
\hline \multicolumn{2}{|l|}{ Ether extract, \% } & 5.87 & 4.90 & 5.74 \\
\hline \multicolumn{2}{|l|}{ Crude fibre, \% } & 3.32 & 3.32 & 3.32 \\
\hline \multicolumn{2}{|l|}{ Starch, \% } & 42.40 & 38.65 & 43.72 \\
\hline \multicolumn{2}{|l|}{ Total sugar, \% } & 5.42 & 5.18 & 3.86 \\
\hline \multicolumn{2}{|c|}{ Metabolizable energy, Kcal/kg } & 3111.4 & 2823.0 & 3085.0 \\
\hline
\end{tabular}

Table 3 Fatty acid composition of raw chickpeas used as a protein source in diets for laying Japanese quail

\begin{tabular}{lr|lr}
\hline Saturated fatty acids & \multicolumn{2}{c}{$\%$} & Unsaturated fatty acids \\
\hline Myristic acid (C14:0) & 0.23 & Palmitoleic acid (C16:1) & 0.73 \\
Palmitic acid (C16:0) & 11.95 & Oleic acid (C18:1) & 34.74 \\
Heptadecanoic acid (C17:0) & 0.08 & Nervonic acid (C24:1) & 0.11 \\
Stearic acid (C18:0) & 2.78 & Monounsaturated fatty acids & 35.58 \\
Arachidic acid (C20:0) & 2.10 & Linoleic acid (C18:2) & 44.63 \\
Behenic acid (C22:0) & 0.34 & Gamma linoleic (C18:3) & 0.07 \\
Lignoceric acid (C24:0) & 0.25 & Alpha linoleic (C18:3) & 0.56 \\
Saturated fatty acids & 17.73 & cis-11.14 eicosadienoic acid (C20:2) & 0.08 \\
& & cis-4.7.10.13.16.19 docosahexaenoic acid (C22:6) & 0.26 \\
Unidentified fatty acids & 1.09 & Polyunsaturated fatty acids & 45.6 \\
\hline
\end{tabular}

This study was carried out in a windowed coop, which belonged to the Department of Animal Science, Faculty of Agriculture, Bingol University. The experiment was designed to have seven groups and three replications, arranged in a completely randomized trial design. A total of 336 laying female Japanese quail were used, with 16 birds in each replication. The experiment was conducted in May-July and completed in nine weeks. The laying quail were housed in multi-storey cage sections during the experiment. The quail in each of the treatment groups were fed ad libitum with isonitrogenous and isocaloric rations containing approximately $20 \%$ crude protein (CP) and $3000 \mathrm{kcal} / \mathrm{kg}$ metabolizable energy (ME) throughout the laying period. The nutrient composition of each diet is shown in Table 4. 
Table 4 Nutrient composition of experimental diets for laying Japanese quail in which chickpeas replaced corn and soybean

\begin{tabular}{lccccccc}
\hline \multirow{2}{*}{ Components, g/kg } & \multicolumn{7}{c}{ Experimental diets } \\
\cline { 2 - 8 } & C0 & RC20 & RC40 & OC20 & OC40 & MC20 & MC40 \\
\hline Dry matter & 899.3 & 908.4 & 917.4 & 908.4 & 917.4 & 908.4 & 917.4 \\
Crude protein & 200.0 & 200.0 & 200.0 & 200.0 & 200.0 & 200.0 & 200.0 \\
Ether extract & 81.3 & 82.3 & 83.3 & 82.3 & 83.3 & 82.3 & 83.3 \\
Crude fibre & 18.3 & 20.9 & 23.4 & 20.9 & 23.4 & 20.9 & 23.4 \\
Crude ash & 116.6 & 115.6 & 114.6 & 115.6 & 114.6 & 115.6 & 114.6 \\
Calcium & 2.80 & 2.80 & 2.80 & 2.80 & 2.80 & 2.80 & 2.80 \\
Phosphorus & 0.65 & 0.65 & 0.65 & 0.65 & 0.65 & 0.65 & 0.65 \\
Tannin & 16.3 & 18.7 & 21.4 & 15.5 & 14.9 & 18.0 & 20.0 \\
& & & & & & & \\
\hline
\end{tabular}

C0: control, RC20: 20\% raw chickpeas, RC40: $40 \%$ raw chickpeas, OC20: 20\% autoclaved chickpeas (OC20), OC40: 40\% autoclaved chickpeas, MC20: 20\% microwaved chickpeas, MC40: 40\% microwaved chickpeas

The treatment effects were assessed by one-way analysis of variance using SAS 9.1.3 statistical package program (SAS Institute Inc., Cary, North Carolina, USA). Duncan's test was used to determine significant differences between means.

\section{Results and Discussion}

The effects of treatments on the egg yolk fat proportions of quail groups were significant at weeks 13 and $19(P<0.01)$, but not at week 16 (Table 3 ). The yolk fat content ranged from $29.31 \%$ to $31.10 \%$ at week 13 , from $30.95 \%$ to $31.52 \%$ at week 16 , and from $29.33 \%$ to $33.35 \%$ at week 19 (Table 5 ). The highest yolk fat was observed in MC20 at week 13, whereas the lowest value was obtained from the control group. At week 19, the highest rate belonged to the RC40 group, whereas the control again had the lowest level again. The eggs of the quail in the control group were found to have lower egg yolk fat content than those of the treatment groups in general. It was reported that the fat and fatty acid contents of rations fed to layer hens were effective in determining the fatty acid profile of the eggs (Grobas et al., 1997; Balevi \& Coskun, 2000; Martino et al., 2002). In the present study, the rations that incorporated chickpeas had $1-2 \%$ more ether extract than the control diet. Thus, an increase in the fat content of egg yolk might be anticipated for the birds that were fed chickpeas, and with few exceptions this was confirmed.

Table 5 Fat contents (\%) of egg yolk from Japanese quail of various ages fed diets that differed in the amount of raw and processed chickpeas

\begin{tabular}{lccc}
\hline Diet & \multicolumn{3}{c}{ Time } \\
\cline { 2 - 4 } & 13th week & 16th week & 19 th week \\
\hline C0 & $29.31 \pm 0.29^{\mathrm{d}}$ & $30.98 \pm 0.50$ & $29.33 \pm 0.46^{\mathrm{d}}$ \\
RC20 & $29.62 \pm 0.10^{\text {cd }}$ & $31.52 \pm 0.23$ & $32.20 \pm 0.39^{\mathrm{ab}}$ \\
RC40 & $30.43 \pm 0.21^{\mathrm{ab}}$ & $31.21 \pm 0.13$ & $33.35 \pm 0.97^{\mathrm{a}}$ \\
OC20 & $30.95 \pm 0.34^{\mathrm{ab}}$ & $30.95 \pm 0.41$ & $30.00 \pm 0.27^{\mathrm{cd}}$ \\
OC40 & $30.47 \pm 0.16^{\mathrm{ab}}$ & $31.41 \pm 0.58$ & $31.52 \pm 0.63^{\mathrm{abc}}$ \\
MC20 & $31.10 \pm 0.17^{\mathrm{a}}$ & $31.07 \pm 0.07$ & $31.02 \pm 0.20^{\mathrm{bcd}}$ \\
MC40 & $30.26 \pm 0.12^{\mathrm{bc}}$ & $31.51 \pm 0.36$ & $31.80 \pm 0.86^{\mathrm{abc}}$ \\
Significance & $P<0.01$ & $P>0.05$ & $P<0.01$
\end{tabular}

C0: control, RC20: 20\% raw chickpeas, RC40: 40\% raw chickpeas, OC20: 20\% autoclaved chickpeas, OC40: 40\% autoclaved chickpeas, MC20: 20\% microwaved chickpeas, MC40: 40\% microwaved chickpeas

a,b,c,d Means with a common superscript did not differ at $P=0.05$ 
Eggs from the 13th and 19th weeks of the trial were assessed for the fatty acid profile of their yolks (Tables 6 and 7). Differences among the treatments became more pronounced with a longer time on the experimental diets. Linoleic acid (C18:2), oleic acid (C18:1), and palmitic acid (C16:0) each made up more than $10 \%$ of the ether extract (approximately $44.6 \%, 34.7 \%$, and $12.0 \%$, respectively) from the chickpeas. Both diets containing autoclaved chickpea meal and the MC20 diet reduced the oleic acid levels in the egg yolks. However, because the MC40 diet was ineffective in affecting the oleic acid level relative to RC40, it may be assumed that the differences among the groups were mainly because of the diet they received. The effects of treatments on the egg yolk palmitic acid levels of the groups were significant at week $13(P<0.01)$, but not at week 19. At week 13, the lowest palmitic acid level $(23.45 \%)$ was obtained from C0. The MC40 group and the RC20 group produced eggs whose yolks had the highest palmitic acid contents. The levels of oleic acid in the egg yolk at the 13th week were not affected significantly by the treatments, but differences between the means at the 19th week were significant $(P<0.01)$. The effects of the treatments on the egg yolk linoleic acid content of the groups were significant at both the 13th and 19th weeks $(P<0.05)$. At the 13th week, the egg yolk linoleic acid content was the higher in the OC40 group than in the other groups, whereas at the 19th week it as elevated in both OC20 and OC40. In this study, the calculated amount of linoleic acid in the rations was not related linearly to the amount found in egg yolk. This result differed somewhat from the findings of Martino et al. (2002) in surubim. Unlike chickpeas, soybean oil is composed of five fatty acids, namely palmitic acid (16:0), stearic acid (18:0), oleic acid (18:1), linoleic acid (18:2), and linolenic acid (18:3). The percentage of these acids in soybean oil averaged $10 \%, 4 \%, 18 \%, 55 \%$, and $13 \%$, respectively (Clemente \& Cahoon, 2009). Steinhilber (2005) found that feeding that was rich in soybean oil increased the linoleic acid content of the egg yolk. Moreover, Shafey et al. (1992) stated that whereas soybean oil in the ration raised the ratio of egg yolk linoleic acid and unsaturated fatty acid to saturated fatty acid, it reduced the ratio of oleic acid to linoleic acid. In the present study, only those birds that were fed raw chickpeas produced eggs in which the oleic acid content of their yolks was increased relative to the control.

The fatty acid profile of chickpeas contained minor amounts of other fatty acids (Table 3). However, several of these fatty acids were modified by the heat treatments compared with raw chickpeas and the control. In the yolks of eggs from birds fed raw chickpeas, the microwave treatment reduced their stearic acid content at the 19th week $(P<0.05)$, whereas this effect was not detected at week 13 . Feeding raw chickpeas might have produced a slightly lower stearic acid content of the egg yolks, and processing them, particularly with microwaves, may have increased it slightly, which is consistent with the results of Calislar and Kaplan (2017). The amount of palmitoleic acid in the egg yolk of the control and treatment groups at week 13 was between $2.71 \%$ and $2.14 \%$ and was not significantly different (Table 6). However, by week 19 it was elevated $(P<0.05)$ for the groups that were fed raw chickpeas compared with the control and heat-treated groups (Table 7). This result supports those of Calislar \& Kaplan (2017) and Cimrin et al. (2019). The chickpeas used in the present study contained $0.07 \%$ gamma-linolenic acid. This is substantially less than the $2.41 \%$ reported by Ryan et al. (2007). No significant differences among treatments in the concentration of gamma-linolenic acid in egg yolk were detected at the 13th week. At the 19th week, the birds fed RC40 produced eggs in which the yolk had a reduced concentration of gamma-linolenic acid compared with all other groups. At week 13, the effects of treatments on changing the amount of egg yolk alpha-linolenic acid was not significant. At the 19th week, the alpha-linolenic acid content of the egg yolk was depressed for birds fed raw and microwaved chickpeas compared with the C0 and OC 20 and OC40 $(P<0.01)$. In this study, no significant relationship was observed between the amount of alpha-linolenic acid of the egg yolk and the alpha-linolenic content of the rations. However, corn, soybean, and soybean oil are reportedly dietary sources of alpha-linolenic acid (Ryan et al., 2007; Gumus \& Aydin, 2013; Balevi \& Coskun, 2000, respectively). Feeding raw chickpeas, which contain very little heptadecanoic acid, may have reduced its level in the egg yolks, whereas the processing treatments may have increased it, although a significant treatment effect $(P<0.05)$ on the heptadecanoic acid content of egg yolks was observed only at week 19. Likewise, significant treatment effects $(P<0.05)$ on the docosahexaenoic acid content of egg yolks were observed only at week 19. In contrast, treatment effects on the behenic acid content of egg yolks was found at week 13 but had dissipated by week $19(P>0.05)$. Treatment effects on the levels of myristic, arachidic, cis-11, 14-eicosadienoic, lignoceric, and nervonic acids were not significant at week 13 or week 19. 
Table 6 Fatty acid levels in the yolks of eggs from Japanese quail fed diets differing in amounts of raw and processed chickpeas in control and treatment groups at 13 th week (\%)

\begin{tabular}{|c|c|c|c|c|c|c|c|c|}
\hline Fatty acids & $\mathrm{CO}$ & $\mathrm{RC} 20$ & $\mathrm{RC} 40$ & OC20 & OC40 & MC20 & MC40 & $P$-value ${ }^{1}$ \\
\hline Palmitic acid & $23.45 \pm 0.37^{c}$ & $25.19 \pm 0.39^{a}$ & $24.23 \pm 0.25^{b c}$ & $24.12 \pm 0.20^{b c}$ & $23.75 \pm 0.34^{b c}$ & $24.47 \pm 0.11^{\mathrm{ab}}$ & $25.29 \pm 0.30^{a}$ & ** \\
\hline Heptadecanoic acid & $0.11 \pm 0.06$ & $0.22 \pm 0.03$ & $0.21 \pm 0.01$ & $0.19 \pm 0.00$ & $0.21 \pm 0.01$ & $0.11 \pm 0.06$ & $0.16 \pm 0.06$ & NS \\
\hline Stearic acid & $10.22 \pm 0.36$ & $10.56 \pm 0.24$ & $10.61 \pm 0.59$ & $10.48 \pm 0.34$ & $10.31 \pm 0.20$ & $10.52 \pm 0.22$ & $10.46 \pm 0.37$ & NS \\
\hline Palmitoleic acid & $2.56 \pm 0.36$ & $2.29 \pm 0.12$ & $2.18 \pm 0.15$ & $2.24 \pm 0.16$ & $2.14 \pm 0.19$ & $2.52 \pm 0.20$ & $2.71 \pm 0.22$ & NS \\
\hline Oleic acid & $37.38 \pm 2.10$ & $37.25 \pm 1.01$ & $37.33 \pm 0.54$ & $37.95 \pm 1.08$ & $36.33 \pm 0.44$ & $39.49 \pm 1.06$ & $38.95 \pm 0.55$ & NS \\
\hline Linoleic acid & $19.14 \pm 1.04^{b}$ & $19.55 \pm 0.45^{b}$ & $20.44 \pm 0.49^{\mathrm{ab}}$ & $20.16 \pm 0.56^{\mathrm{ab}}$ & $22.04 \pm 0.42^{a}$ & $18.24 \pm 0.98^{b}$ & $18.10 \pm 0.69^{b}$ & * \\
\hline Gamma-linolenic acid & $0.49 \pm 0.26$ & $0.24 \pm 0.01$ & $0.26 \pm 0.01$ & $0.26 \pm 0.01$ & $0.30 \pm 0.01$ & $0.22 \pm 0.00$ & $0.24 \pm 0.02$ & NS \\
\hline Alpha-linolenic acid & $0.64 \pm 0.33$ & $0.98 \pm 0.05$ & $1.00 \pm 0.04$ & $1.01 \pm 0.05$ & $1.10 \pm 0.02$ & $0.86 \pm 0.07$ & $0.72 \pm 0.05$ & NS \\
\hline Myristic acid & $0.41 \pm 0.02$ & $0.27 \pm 0.14$ & $0.40 \pm 0.01$ & $0.40 \pm 0.01$ & $0.40 \pm 0.01$ & $0.39 \pm 0.02$ & $0.39 \pm 0.01$ & NS \\
\hline Arachidic acid & $0.13 \pm 0.02$ & $0.07 \pm 0.04$ & $0.11 \pm 0.00$ & $0.11 \pm 0.01$ & $0.11 \pm 0.00$ & $0.11 \pm 0.00$ & $0.12 \pm 0.01$ & NS \\
\hline cis-11,14-eicosadienoic acid & $0.25 \pm 0.19$ & $0.11 \pm 0.00$ & $0.11 \pm 0.00$ & $0.07 \pm 0.04$ & $0.12 \pm 0.01$ & $0.03 \pm 0.03$ & $0.04 \pm 0.04$ & NS \\
\hline Behenic acid & $1.77 \pm 0.02^{\mathrm{a}}$ & $0.00 \pm 0.00^{\mathrm{b}}$ & $0.00 \pm 0.00^{\mathrm{b}}$ & $0.00 \pm 0.00^{\mathrm{b}}$ & $0.00 \pm 0.00^{\mathrm{b}}$ & $0.00 \pm 0.00^{\mathrm{b}}$ & $0.60 \pm 0.60^{\mathrm{b}}$ & $* *$ \\
\hline Lignoceric acid & $0.29 \pm 0.15$ & $0.12 \pm 0.01$ & $0.16 \pm 0.01$ & $0.14 \pm 0.01$ & $0.15 \pm 0.02$ & $0.14 \pm 0.01$ & $0.16 \pm 0.03$ & NS \\
\hline Nervonic acid & $0.23 \pm 0.05$ & $0.18 \pm 0.01$ & $0.20 \pm 0.01$ & $0.21 \pm 0.02$ & $0.21 \pm 0.02$ & $0.17 \pm 0.01$ & $0.17 \pm 0.01$ & NS \\
\hline Docosahexaenoic acid & $1.01 \pm 0.17$ & $0.81 \pm 0.02$ & $0.88 \pm 0.03$ & $0.83 \pm 0.03$ & $0.92 \pm 0.05$ & $0.88 \pm 0.06$ & $0.69 \pm 0.01$ & NS \\
\hline Total saturated fatty acids & $36.39 \pm 0.28$ & $36.43 \pm 0.37$ & $35.72 \pm 0.80$ & $35.43 \pm 0.50$ & $34.93 \pm 0.51$ & $35.74 \pm 0.18$ & $37.17 \pm 0.73$ & NS \\
\hline Monounsaturated fatty acids & $40.17 \pm 2.34$ & $39.72 \pm 1.13$ & $39.72 \pm 0.49$ & $40.40 \pm 1.18$ & $38.69 \pm 0.64$ & $42.18 \pm 1.24$ & $41.83 \pm 0.76$ & NS \\
\hline Polyunsaturated fatty acids & $21.53 \pm 1.21^{b c}$ & $21.68 \pm 0.48^{\mathrm{bc}}$ & $22.68 \pm 0.49^{\mathrm{ab}}$ & $22.34 \pm 0.64^{\mathrm{abc}}$ & $24.47 \pm 0.40^{a}$ & $20.24 \pm 1.10^{\mathrm{bc}}$ & $19.78 \pm 0.71^{c}$ & * \\
\hline Total unsaturated fatty acids & $61.70 \pm 1.46$ & $61.41 \pm 0.67$ & $62.40 \pm 0.79$ & $62.74 \pm 0.56$ & $63.16 \pm 0.43$ & $62.41 \pm 0.22$ & $61.61 \pm 0.50$ & NS \\
\hline
\end{tabular}

C0: control, RC20: 20\% raw chickpeas, RC40: 40\% raw chickpeas, OC20: 20\% autoclaved chickpeas (OC20), OC40: 40\% autoclaved chickpeas, MC20: 20\% microwaved chickpeas, MC40: 40\% microwaved chickpeas

a,b,c Within a row, means with a common superscript were not different at $P=0.05$

${ }^{1} \mathrm{NS}$ : insignificant, ${ }^{\star} P<0.05$, ${ }^{\star *} P<0.01$ 
Table 7 Fatty acid levels in yolks of eggs from Japanese quail fed diets differing in amounts of raw and processed chickpeas in control and treatment groups at 19th week (\%)

\begin{tabular}{|c|c|c|c|c|c|c|c|c|}
\hline Fatty acids & $\mathrm{CO}$ & RC20 & $\mathrm{RC40}$ & OC20 & OC40 & MC20 & MC40 & $P$-value \\
\hline Palmitic acid & $22.97 \pm 0.39$ & $24.93 \pm 0.35$ & $25.12 \pm 0.48$ & $23.24 \pm 0.35$ & $23.17 \pm 0.37$ & $24.61 \pm 1.07$ & $24.05 \pm 0.39$ & NS \\
\hline Heptadecanoic acid & $0.19 \pm 0.01^{\mathrm{abc}}$ & $0.15 \pm 0.01^{c}$ & $0.16 \pm 0.01^{c}$ & $0.21 \pm 0.01^{\mathrm{abc}}$ & $0.22 \pm 0.00^{\mathrm{ab}}$ & $0.24 \pm 0.04^{a}$ & $0.17 \pm 0.01^{b c}$ & * \\
\hline Stearic acid & $10.90 \pm 0.16^{\mathrm{abc}}$ & $10.14 \pm 0.11^{c}$ & $10.09 \pm 0.18^{c}$ & $10.61 \pm 0.39^{b c}$ & $11.02 \pm 0.50^{\mathrm{abc}}$ & $11.56 \pm 0.01^{\mathrm{a}}$ & $11.39 \pm 0.18^{\mathrm{ab}}$ & * \\
\hline Palmitoleic acid & $2.14 \pm 0.11^{\mathrm{b}}$ & $2.81 \pm 0.15^{\mathrm{a}}$ & $2.88 \pm 0.22^{\mathrm{a}}$ & $2.07 \pm 0.30^{\mathrm{b}}$ & $1.79 \pm 0.11^{\mathrm{b}}$ & $1.91 \pm 0.02^{\mathrm{b}}$ & $2.16 \pm 0.18^{b}$ & ** \\
\hline Oleic acid & $36.89 \pm 0.21^{b c}$ & $39.34 \pm 0.32^{a}$ & $39.55 \pm 0.43^{a}$ & $36.79 \pm 1.17^{\mathrm{bc}}$ & $35.70 \pm 0.34^{c}$ & $36.28 \pm 0.32^{c}$ & $38.80 \pm 0.79^{\mathrm{ab}}$ & $* *$ \\
\hline Linoleic acid & $21.40 \pm 0.62^{\mathrm{ab}}$ & $18.12 \pm 0.73^{b c}$ & $17.86 \pm 1.10^{c}$ & $22.02 \pm 1.28^{\mathrm{a}}$ & $22.79 \pm 0.53^{a}$ & $20.02 \pm 1.36^{\mathrm{abc}}$ & $18.62 \pm 0.99 b c$ & * \\
\hline Gamma-linolenic acid & $0.29 \pm 0.01^{a}$ & $0.23 \pm 0.02^{\mathrm{a}}$ & $0.10 \pm 0.10^{b}$ & $0.29 \pm 0.02^{\mathrm{a}}$ & $0.30 \pm 0.03^{a}$ & $0.23 \pm 0.02^{\mathrm{a}}$ & $0.24 \pm 0.01^{a}$ & * \\
\hline Alpha-linolenic acid & $1.09 \pm 0.069^{a b}$ & $0.73 \pm 0.06^{c}$ & $0.71 \pm 0.09^{c}$ & $1.14 \pm 0.06^{a}$ & $1.10 \pm 0.07^{a b}$ & $0.90 \pm 0.06^{b c}$ & $0.69 \pm 0.07^{c}$ & $* *$ \\
\hline Myristic acid & $0.40 \pm 0.01$ & $0.40 \pm 0.01$ & $0.39 \pm 0.03$ & $0.39 \pm 0.00$ & $0.38 \pm 0.03$ & $1.04 \pm 0.67$ & $0.38 \pm 0.02$ & NS \\
\hline Arachidic acid & $0.16 \pm 0.05$ & $0.11 \pm 0.01$ & $0.12 \pm 0.02$ & $0.07 \pm 0.04$ & $0.11 \pm 0.01$ & $0.11 \pm 0.01$ & $0.10 \pm 0.01$ & NS \\
\hline cis-11,14-eicosadienoic acid & $0.08 \pm 0.04$ & $0.12 \pm 0.01$ & $0.11 \pm 0.01$ & $0.11 \pm 0.01$ & $0.11 \pm 0.00$ & $0.03 \pm 0.03$ & $0.11 \pm 0.01$ & NS \\
\hline Behenic acid & $2.03 \pm 0.04$ & $0.59 \pm 0.59$ & $0.89 \pm 0.90$ & $1.14 \pm 0.57$ & $1.84 \pm 0.03$ & $1.68 \pm 0.16$ & $2.05 \pm 0.07$ & NS \\
\hline Lignoceric acid & $0.13 \pm 0.01$ & $0.15 \pm 0.03$ & $0.10 \pm 0.11$ & $0.13 \pm 0.01$ & $0.15 \pm 0.02$ & $0.09 \pm 0.05$ & $0.17 \pm 0.02$ & NS \\
\hline Nervonic acid & $0.20 \pm 0.02$ & $0.16 \pm 0.00$ & $0.08 \pm 0.08$ & $0.18 \pm 0.01$ & $0.18 \pm 0.02$ & $0.16 \pm 0.01$ & $0.18 \pm 0.01$ & NS \\
\hline Docosahexaenoic acid & $0.96 \pm 0.04^{\mathrm{a}}$ & $0.68 \pm 0.01^{a}$ & $0.35 \pm 0.35^{b}$ & $0.91 \pm 0.06^{\mathrm{a}}$ & $0.96 \pm 0.06^{a}$ & $0.83 \pm 0.09^{a}$ & $0.85 \pm 0.05^{a}$ & * \\
\hline Total saturated fatty acids & $36.79 \pm 0.58$ & $36.47 \pm 0.86$ & $36.87 \pm 1.08$ & $35.79 \pm 0.63$ & $36.89 \pm 0.90$ & $39.33 \pm 1.57$ & $38.31 \pm 0.19$ & NS \\
\hline Monounsaturated fatty acids & $39.23 \pm 0.19^{b c}$ & $42.31 \pm 0.46^{a}$ & $42.51 \pm 0.57^{a}$ & $39.05 \pm 1.46^{\mathrm{bc}}$ & $37.67 \pm 0.29^{c}$ & $38.34 \pm 0.33^{c}$ & $41.13 \pm 0.92^{\mathrm{ab}}$ & $\star *$ \\
\hline Polyunsaturated fatty acids & $23.83 \pm 0.68^{\mathrm{ab}}$ & $19.88 \pm 0.78^{c}$ & $19.13 \pm 1.43^{c}$ & $24.47 \pm 1.42^{\mathrm{a}}$ & $25.27 \pm 0.55^{\mathrm{a}}$ & $22.01 \pm 1.54^{\mathrm{abc}}$ & $20.52 \pm 1.12^{b c}$ & * \\
\hline Total unsaturated fatty acids & $63.06 \pm 0.54$ & $61.19 \pm 0.32$ & $61.64 \pm 0.86$ & $63.52 \pm 0.17$ & $62.95 \pm 0.84$ & $60.36 \pm 1.72$ & $61.65 \pm 0.20$ & NS \\
\hline
\end{tabular}

C0: control, RC20: 20\% raw chickpeas, RC40: 40\% raw chickpeas, OC20: 20\% autoclaved chickpeas (OC20), OC40: 40\% autoclaved chickpeas, MC20: 20\% microwaved chickpeas, MC40: $40 \%$ microwaved chickpeas

a,b,c Within a row, means with a common superscript were not different at $P=0.05$

${ }^{1} \mathrm{NS}$ : insignificant, ${ }^{*} P<0.05,{ }^{*} P<0.01$ 
Differences in the total saturated fatty acid content of the egg yolks at weeks 13 and 19 were insignificant (Tables 6 and 7). Tokusoglu (2006) stated that raw quail egg contains $23.90 \%$ total saturated fatty acids, a level that is substantially lower than the present observations. Likewise, treatments effects on the total unsaturated fatty acid content of the egg yolks were not significant at week 13 or week 19 . When the data obtained at the 13th week were analysed, the treatment effects on the quantity of monounsaturated fatty acids (MUFA) in the egg yolks were insignificant $(P>0.05)$, but these effects became significant at the 19th week $(P<0.01)$. Feeding raw chickpeas increased the level of MUFA in the egg yolks relative to the control. With the exception of the MC40 diet, this effect was mitigated by the heat treatments. The raw chickpeas in this study had $35.58 \%$ MUFA content. Corn, soybean, and soybean oil all contain important quantities of MUFAs (Ryan et al., 2007; Gumus \& Aydin, 2013; Balevi \& Coskun, 2000, respectively). Tokusoglu (2006) reported that raw quail egg contained $30.34 \%$ of total MUFA, which is substantially less than was observed for any of the groups in the present study. The chickpeas in this study were rich in polyunsaturated fatty acids (PUFAs) (Table 3). Corn, soybean and soybean oil are reportedly also all high in PUFAs (Ryan et al., 2007; Gumus \& Aydin, 2013; Balevi \& Coskun, 2000, respectively). The treatment effects on the PUFA content of the egg yolks at weeks 13 and 19 were significant $(P<0.05)$. At the 13th week, the PUFA content of egg yolk produced by OC40 was significantly elevated relative to the other treatment groups. However, at the 19th week, this effect had largely dissipated, and the groups fed raw chickpeas were exhibiting decreased levels of PUFA in the yolks of the eggs they produced. Tokusoglu (2006) stated that raw quail eggs contained $13.86 \%$ of total PUFA, a level that is lower than the present findings. It was concluded that the autoclaving process reduced the MUFA content of the egg yolk compared with raw chickpeas, and microwaving elevated it. In contrast, observed blood serum metabolites indicated reduced lipid metabolism by birds fed heat-treated soybean meal (Nahavandinejad et al., 2014).

The differences in the egg yolk cholesterol content of egg yolks at 13 and 19 weeks old were affected significantly by the diets containing raw and heat-treated chickpeas (Table 8). In both weeks, the treatments affected the cholesterol content of the egg yolks. From the 13th week to the 19th week, the cholesterol levels of the C0 and RC40 groups increased significantly, and those in the OC40, MC20 and MC40 groups decreased significantly. The cholesterol levels did not change over time in the RC20 and OC20 groups. The results showed that the heat treatments (autoclaving and microwave) reduced the egg yolk cholesterol level significantly (excluding the OC20 group). These findings were similar to those of Milinsk et al. (2003) and Carrillo-Domìnguez et al. (2005).

Table 8 Cholesterol levels $(\mathrm{mg})$ in yolks of eggs from Japanese quail fed diets that differed in amounts of raw and processed chickpeas in control and treatment groups at 13 and 19 weeks old

\begin{tabular}{ccccccccc}
\hline Week & C0 & RC20 & RC40 & OC20 & OC40 & MC20 & MC40 & $P$-value \\
\cline { 2 - 8 } 13 & $42.0 \pm 3.6^{\mathrm{d}}$ & $70.4 \pm 2.9^{\mathrm{a}}$ & $51.3 \pm 4.1^{\mathrm{dc}}$ & $65.4 \pm 3.4^{\mathrm{ab}}$ & $59.0 \pm 1.9^{\mathrm{bc}}$ & $67.4 \pm 3.9^{\mathrm{ab}}$ & $66.1 \pm 3.2^{\mathrm{ab}}$ & $<0.01$ \\
19 & $71.1 \pm 3.3^{\mathrm{a}}$ & $69.6 \pm 4.4^{\mathrm{a}}$ & $62.6 \pm 1.6^{\mathrm{ab}}$ & $65.0 \pm 3.9^{\mathrm{ab}}$ & $48.7 \pm 2.9^{\mathrm{c}}$ & $56.4 \pm 3.9^{\mathrm{bc}}$ & $56.7 \pm 5.3^{\mathrm{bc}}$ & $<0.01$
\end{tabular}

C0: control, RC20: 20\% raw chickpeas, RC40: 40\% raw chickpeas, OC20: 20\% autoclaved chickpeas (OC20), OC40: 40\% autoclaved chickpeas, MC20: 20\% microwaved chickpeas, MC40: 40\% microwaved chickpeas a,b,c,d Within a row, means with a common superscript were not different at $P=0.05$

Significant differences among the treatments were detected only for ALT, with the other constituents not being different among the groups. The blood glucose results were similar to those of Azeemi et al. (2015) and Algam et al. (2013). Likewise, the recorded ion concentrations were similar across the groups. Metabolic parameters such as serum lipoprotein, cholesterol and glucose levels of poultry change depending on the composition of their diet (Crespo \& Esteve-Garcia, 2003). In poultry, exogenous lipids affect blood lipid levels, and thus triglyceride (TG) levels may be altered (Serr et al., 2009). The serum TG in the present study was similar to those reported by Algam et al. (2013) in broilers and Wang \& Mcintosh (1996) in rats, but differed from the report of Djeddi (1999). A linear relationship was found between cholesterol content of the egg yolks and serum cholesterol and low-density lipoprotein (LDL) levels. Levels of glucose, albumin, globulin, total protein, TG, LDL-cholesterol, total cholesterol, alkaline phosphatase (ALP), aspartate aminotransferase (AST), Lactic acid dehydrogenase (LDH), chlorine, phosphorus (P), magnesium (Mg), potassium $(\mathrm{K})$, calcium $(\mathrm{Ca})$, and Iron $(\mathrm{Fe})$ of the serum samples at the 19 th week are presented in Table 9. 
Table 9 Serum constituents of Japanese quail fed diets differing in amounts of raw and processed chickpeas in control and treatment groups at 19th week

\begin{tabular}{|c|c|c|c|c|c|c|c|c|}
\hline Constituent & $\mathrm{CO}$ & $\mathrm{RC} 20$ & $\mathrm{RC} 40$ & OC20 & OC40 & MC20 & MC40 & $P$-value \\
\hline Glucose, mg/dL & $278.7 \pm 33.3$ & $297.7 \pm 6.7$ & $419.3 \pm 109.8$ & $309.3 \pm 15.4$ & $298.7 \pm 11.7$ & $332.0 \pm 6.9$ & $318.3 \pm 30.3$ & NS \\
\hline Triglycerides. mg/dL & $1181.7 \pm 174.3$ & $1169.7 \pm 150.5$ & $932.7 \pm 316.2$ & $659.0 \pm 37.89$ & $682.7 \pm 352.7$ & $607.0 \pm 14.7$ & $833.0 \pm 31.0$ & NS \\
\hline Total cholesterol, mg/dL & $222.0 \pm 75.2$ & $208.3 \pm 43.5$ & $160.3 \pm 46.9$ & $143.3 \pm 8.9$ & $131.3 \pm 44.3$ & $108.7 \pm 13.4$ & $125.3 \pm 2.6$ & NS \\
\hline LDL, mg/dL & $89.3 \pm 39.9$ & $106.9 \pm 34.9$ & $71.2 \pm 27.0$ & $61.8 \pm 5.9$ & $90.5 \pm 21.4$ & $56.3 \pm 7.4$ & $101.5 \pm 7.5$ & NS \\
\hline Total protein, g/dL & $4.50 \pm 0.45$ & $4.30 \pm 0.32$ & $4.63 \pm 0.58$ & $4.50 \pm 0.20$ & $3.87 \pm 0.51$ & $3.40 \pm 0.62$ & $3.37 \pm 2.27$ & NS \\
\hline Albumen, g/dL & $0.79 \pm 0.15$ & $0.89 \pm 0.15$ & $0.85 \pm 0.18$ & $1.06 \pm 0.08$ & $0.95 \pm 0.07$ & $0.67 \pm 0.17$ & $0.71 \pm 0.16$ & NS \\
\hline Globulin, g/dL & $3.70 \pm 0.31$ & $3.40 \pm 0.14$ & $3.80 \pm 0.52$ & $3.45 \pm 0.25$ & $2.90 \pm 0.48$ & $2.75 \pm 0.51$ & $2.66 \pm 0.38$ & NS \\
\hline ALP, IU/L & $948.7 \pm 405.7$ & $919.0 \pm 116.1$ & $1333.7 \pm 329.6$ & $1319.0 \pm 549.0$ & $810.0 \pm 182.1$ & $853.7 \pm 251.2$ & $734.7 \pm 66.2$ & NS \\
\hline ALT, IU/L & $4.00 \pm 0.58^{\mathrm{ab}}$ & $2.00 \pm 0.00^{c}$ & $4.33 \pm 0.33^{a}$ & $3.00 \pm 0.00^{b c}$ & $3.00 \pm 0.58^{b c}$ & $4.67 \pm 0.33^{a}$ & $2.67 \pm 0.33^{c}$ & $<0.01$ \\
\hline AST, IU/L & $237.3 \pm 51.56$ & $257.0 \pm 56.82$ & $223.3 \pm 8.81$ & $254.0 \pm 31.00$ & $205.3 \pm 6.33$ & $197.3 \pm 29.35$ & $211.3 \pm 34.10$ & NS \\
\hline LDH, IU/L & $687.7 \pm 119.9$ & $724.7 \pm 90.93$ & $681.0 \pm 112.32$ & $667.0 \pm 180.2$ & $730.3 \pm 218.0$ & $736.0 \pm 293.1$ & $701.0 \pm 82.59$ & NS \\
\hline Calcium, mg/dL & $20.19 \pm 3.21$ & $22.29 \pm 1.46$ & $21.08 \pm 4.07$ & $15.00 \pm 1.81$ & $16.17 \pm 3.92$ & $15.68 \pm 0.65$ & $15.23 \pm 1.49$ & NS \\
\hline Phosphorus, mg/dL & $9.70 \pm 2.36$ & $10.33 \pm 1.24$ & $9.90 \pm 2.40$ & $6.43 \pm 1.04$ & $7.03 \pm 1.39$ & $6.60 \pm 0.81$ & $6.33 \pm 1.62$ & NS \\
\hline Magnesium, mg/dL & $5.32 \pm 0.61$ & $6.08 \pm 0.17$ & $5.43 \pm 0.54$ & $4.91 \pm 0.61$ & $4.80 \pm 0.42$ & $5.10 \pm 0.21$ & $5.04 \pm 0.56$ & NS \\
\hline Potassium, mmol/L & $4.63 \pm 0.43$ & $4.17 \pm 0.05$ & $4.20 \pm 0.08$ & $4.35 \pm 0.25$ & $4.16 \pm 0.05$ & $4.53 \pm 0.26$ & $4.75 \pm 0.11$ & NS \\
\hline Iron, $\mu \mathrm{g} / \mathrm{dL}$ & $941.3 \pm 197.4$ & $1164.3 \pm 167.0$ & $928.8 \pm 141.6$ & $602.7 \pm 176.6$ & $663.0 \pm 296.0$ & $612.0 \pm 22.81$ & $657.0 \pm 114.1$ & NS \\
\hline Chloride, $\mathrm{mmol} / \mathrm{L}$ & $89.2 \pm 1.79$ & $92.3 \pm 2.98$ & $87.4 \pm 1.24$ & $87.9 \pm 1.48$ & $77.4 \pm 9.40$ & $88.7 \pm 1.87$ & $88.5 \pm 0.98$ & NS \\
\hline
\end{tabular}

C0: control, RC20: 20\% raw chickpeas, RC40: 40\% raw chickpeas, OC20: $20 \%$ autoclaved chickpeas (OC20), OC40: 40\% autoclaved chickpeas, MC20: 20\% microwaved chickpeas, MC40: 40\% microwaved chickpeas

a,b,c, Within a row, means with a common superscript were not different at $P=0.05$

LDL: low-density lipoprotein, ALP: alkaline phosphatase, ALT: Alanine Aminotransferase, AST: aspartate aminotransferase, LDH: lactic acid dehydrogenase 
Serum albumin and globulin levels were similar among the groups $(P>0.05)$. Total protein across treatments was similar to the findings of Djeddi (1999), Algam et al. (2013) and Sehu et al. (1996). In contrast, blood serum metabolites in all diets containing heat-treated soybean meal indicated higher protein metabolism (Nahavandinejad et al., 2014).

In this study, serum ALP, ALT, AST and LDH were measured to determine the negative impacts of anti-nutritional factors in grain chickpeas might create in the liver of quail. The blood ALT levels of the groups ranged from $2.0 \mathrm{IU} / \mathrm{L}$ to $4.67 \mathrm{IU} / \mathrm{L}$, and there were significant differences $(P<0.01)$ between the groups. However, treatment effects are difficult to interpret biologically. Differences in the blood ALP, AST, and LDH levels between the treatments were not significant.

Because the chickpeas in this study may have contained anti-nutritional factors, analyses were performed to determine whether the heat treatments caused changes in the mineral profile of the serum. The differences between the groups in blood $\mathrm{Mg}, \mathrm{K}, \mathrm{Fe}$, and chloride levels were not significant. El-Adawy (2006) and Alajaji and El-Adawy (2006) reported that heat treatment applied to chickpeas results in mineral losses, and that mineral losses in microwave processing are lower than in autoclaving. However, the observed lack of difference in serum Ca and P was similar to the findings of Djeddi (1999) and Algam et al. (2013). The thermal treatments applied to soybean meal by Nahavandinejad et al. (2014) did not influence the serum concentrations of $\mathrm{Ca}$ or $\mathrm{P}$.

\section{Conclusion}

In this study, chickpeas replaced corn and soybean meal in rations for Japanese quail. Various heat treatments were applied to the chickpeas to minimize the adverse effects of phenolic compounds and antinutritional elements. In general, although many of the treatment effects were significant, they were of relatively small magnitude. Heat treatments minimize the adverse effect of anti-nutritional elements in the raw chickpea structure, and microwaving caused less loss in the mineral content of the chickpea than the autoclave process. Applying autoclave and microwave heat treatments to chickpeas had similar modest and beneficial effects on the physiology of the quail. These results have provided hope that chickpeas may be used effectively in poultry feed.

\section{Acknowledgements}

The authors would like to express their gratitude to Kahramanmaras Sutcu Imam University Research Fund for supporting this research (BAP-Project number 2014/2-46D)

\section{Authors' Contributions}

Both authors participated in all aspects of the study.

\section{Conflict of Interest Declaration}

Authors declared there was no conflict of interest regarding the content of this article.

\section{References}

Alajaji, S.A. \& El-Adawy, T.A., 2006. Nutritional composition of chickpea (Cicer arietinum L.) as affected by microwave cooking and other traditional cooking methods. Food Chem. 19(8), 806-812. doi: 10.1016/j.jfca.2006.03.015

Algam, T.A., Atti, K.A.A., Dousa, B.M., Elawad, S.M. \& Elseed, A.M.F., 2013. Effect of dietary raw chickpea (Cicer arietinum I.) seeds on broiler performance and blood constituents. Int. J. Poult. Sci. 11, 294-297.

Ayasan, T., Ulger, I., Kaliber, M., Ergul, S., Mart, D. \& Turker, M., 2018. Comparison of In vitro gas production, nutritive value, metabolizable energy and organic matter digestibility of some chickpea varieties. Iran. J. Appl. Anim. Sci. 18(1), 131-136.

Azeemi, T.A, Asif, M. \& Niazi M., 2015. Effect of olive leaves extract on lipid profile, glucose and feed intake of Japanese quail. TURJAF 3(11), 874-876

Balevi, T. \& Coskun, B., 2000. Effects of some dietary oils on performance and fatty acid composition of eggs in layers. Rev. Med. Vet. 151, 847-854.

Bampidis, V.A. \& Christodoulou, V., 2011 Chickpeas (Cicer arietinum I.) in animal nutrition: A review. Anim. Feed Sci. Tech. 168, 1-20.

Calislar, S. \& Kaplan, Y., 2017. Effects of carob (Ceratonia siliqua) pod byproduct on quail performance, egg characteristics, fatty acids, and cholesterol levels. R. Bras. Zootec. 46(2), 113117. https://DOl.org/10.1590/s1806-92902017000200005

Carrillo-Dominguez, S., Carranco-Jauregui, M.E., Castillo-Dominguez, R.M., Castro-Gonzalez, M.I., Avila-Gonzalez, E. \& Perez-Gil, F., 2005. Cholesterol and N-3 and N-6 fatty acid content in eggs from laying hens fed with red crab meal (Pleuroncodes planipes). Poult. Sci. 84, 167-172. 
Cimrin, T., Avsaroglu, M.D., Tunca, R.I., Kandır, S. \& Ayasan, T., 2019. Effects of the dietary supplementation of layer diets with natural and synthetic antioxidant additives on yolk lipid peroxidation and fatty acid composition of eggs stored at different temperatures and duration. Braz. J. Poultry Sci. 21(2), 1-8.

Clemente, T.E. \& Cahoon, E.B., 2009. Soybean oil: Genetic approaches for modification of functionality and total content. Plant Physiol. 151(3),1030-1040. DOI:10.1104/pp.109.146282

Crespo, N. \& Esteve-Garcia, E., 2003. Polyunsaturated fatty acids reduce insulin and very low density lipoprotein levels in broiler chickens. Poult. Sci. 82, 1134-1139.

Djeddi, A.N., 1999. Bildircin rasyonlarina katilan figin yumurta verimi ve kalitesi ile bazi kan parametrelerine etkisi. Ankara Univ. Vet. Fak. Derg. 46, 9-19.

El-Adawy, T.A., 2002. Nutritional composition and antinutritional factors of chickpeas (Cicer arietinum I.) undergoing different cooking methods and germination. Plant Food Hum. Nutr. 57, 83-97.

Eskibalci, M.F. \& Ozkan, S.G., 2008. Mikrodalga enerjisinin cevher hazirlamadaki uygulamalari ve bor minerallerinin ogutulebilirligine olan etkilerinin incelenmesi. Ist. Earth Sci. 11-23.

Gatel, F., 1994. Protein quality of legumes seeds for non-ruminant animals: A review. Anim. Feed. Sci. Tech. 45, 317348.

Gerard, K.A. \& Roberts, J.S., 2004. Microwave heating of apple mash to improve juice yield and quality. Lwt - Sci. Technol. 37, 551-557.

Grobas, S., Mendez, J., De Blas, C. \& Mateos, G.G., 1997. Influence of levels of vitamin E and type of dietary fat on concentration of $\alpha$-tocopherol oxidative status and fatty acid profile of egg yolks. Poult. Sci. 76, 93.

Gumus, E. \& Aydin, B., 2013. Effect of poultry by-product meal on growth performance and fatty acid composition of carp (Cyprinus carpio) fry. Turk. J. Fish. Aquat. Sc. 13, 827-834

Gungor, A. \& Atalay, U., 1999. Grindability of microwave-heated ores. In: Proceedings of the SME Annual Meeting Denver, Colorado, USA. 1-3 March 1999.

Jezierny, D., Mosenthin, R. \& Weiss, E., 2010. The use of grain legumes as a protein source in pig nutrition: A review. Anim. Feed Sci. Tech. 157(3), 111-128.https://doi.org/10.1016/j.anifeedsci.2010.03.001

Kaya, I. \& Yalcin, S. 1999. Baklagil tane yemleri ve ruminant rasyonlarinda kullanimi, Lalahan. Hayvanc. Araşt. Enst. Derg. 39, 101-114.

Kumar, R., 1992. Anti-nutritional factors, the potential risks of toxicity and methods to alleviate them. In: Legume Trees and Other Fodder Trees as Protein Sources for Livestock: Proceedings of the FAO Expert Consultation Held at the Malaysian Agricultural Research and Development Institute (MARDI) in Kuala Lumpur, Malaysia, 14-18 October 1991. FAO, Rome, Italy.

Martino, R.C., Cyrino, J.E.P., Portz, L. \& Trugo, L.C., 2002. Performance and fatty acid composition of surubim (Pseudoplatystoma coruscans) fed diets with animal and plant lipids. Aquaculture 209, 233-246

Milinsk, M.C., Murakami, A.E., Gomes, S.T.M., Matsushita, M. \& De Souza, N.E., 2003. Fatty acid profile of egg yolk lipids from hens fed diets rich in n-3 fatty acids. Food Chem. 83, 287-292.

Muszyński, S., Kwiecień, M., Świetlicki, M., Dobrowolski, P., Tatarczak, J. \& Gładyszewska, B., 2018. The effects of replacing soybean meal with chickpea seeds in the diet on mechanical and thermal properties of tendon tissue in broiler chicken. Poult. Sci. 97, 695-700.

Nahavandinejad, M., Seidavi, A., Asadpour, L. \& Payan-Carreira, R., 2014. Blood biochemical parameters of broilers fed differently thermal processed soybean meal. Rev. MVZ. Cordoba. 19, 4301-4315.

Ozdemir, F., Golukcu, M. \& Topuz, A., 2003. Yer fistiginin (arachis hypogaea) bazi fiziksel ve kimyasal ozellikleri ve fistik kavurmada mikrodalga uygulamasinin yag asitleri bilesimi uzerine olan etkisi. Gida 28, 39-45.

Ryan, J., Ibrikci, H., Singh, M., Matar,, A., Masri S., Rashid, A. \& Pala, M., 2007. Response to residual and currently applied phosphorus in dryland cereal/legume rotations in three Syrian Mediterranean agroecosystems. Eur. $J$. Agron. 28, 126-137.

Serr, J., Suh, Y. \& Lee, K., 2009. Regulation of adipose triglyceride lipase by fasting and refeeding in avian species. Poult. Sci. 88, 2585-2591.

Shafey, T.M., Dingle, J.G. \& McDonald, M.W., 1992. Comparison between wheat, triticale, rye, soybean oil and strain of laying bird on the production and cholesterol and fatty acid contents of eggs. Br. Poult. Sci. 33, 339-346.

Steinhilber, S.H., 2005. Influence of strain and age of hen and dietary fat on the incorporation of omega-3 fatty acids into chicken eggs and on egg quality parameters. Arch. Geflugelkd. 69, 94-95.

Sehu, A., Yalcin, S. \& Karakas, F., 1996. Bildircin rasyonlarina katilan burcagin (Vicia ervilia l.) buyume, karkas randimani ve bazi kan parametreleri uzerine etkisi. Ankara. Univ. Vet. Fak. Derg. 43, 271-276.

Tokusoglu, O., 2006. The quality properties and saturated and unsaturated fatty acid profiles of quail egg: The alterations of fatty acids with process effects. Int. J. Food Sci. Nutr. 57, 537-545.

Wang, Y.H.A. \& Mclntosh, G.H., 1996. Extrusion and boiling improve rat body weight gain and plasma cholesterol lowing ability of peas and chickpeas. J. Nutr. 126, 3054-3062, 